\title{
Sex segregation as policy problem: a gendered policy paradox
}

\section{Elizabeth A. Sharrow}

To cite this article: Elizabeth A. Sharrow (2021) Sex segregation as policy problem: a gendered policy paradox, Politics, Groups, and Identities, 9:2, 258-279, DOI: 10.1080/21565503.2019.1568883

To link to this article: https://doi.org/10.1080/21565503.2019.1568883

\section{Published online: 21 Jan 2019.}

Submit your article to this journal $\square$

\section{Џll Article views: 260}

Q View related articles ๘

View Crossmark data $₫$ 


\title{
Sex segregation as policy problem: a gendered policy paradox
}

\author{
Elizabeth A. Sharrow \\ Department of Political Science, Department of History, University of Massachusetts Amherst, Amherst, MA, \\ USA
}

\begin{abstract}
2017 marked the 45th anniversary of Title IX of the Education Amendments of 1972, a sex non-discrimination policy which remade American education and athletics. Has Title IX fulfilled its promise to end discriminatory and disparate treatment of women in educational institutions? This article places policy in conversation with scholarly debate over how to best tackle persistent sex and gender inequalities, illustrating that the athletic policy sphere both addresses and reproduces sexist practices. It examines the under-appreciated complexity of sex equity politics and suggests the need to question how well public policy addresses inequalities. It argues that we are losing ground in the struggle to end gendered oppression - despite all that it may appear we have gained - because of Title IX's divergent implementation strategy which integrates women and men in classrooms and segregates them in sports. Rather than vitiating sex discrimination, implementation generated a series of policy ironies, authorizing, rather than challenging the notion that women and men are inherently "different." In order to continue addressing the ways in which gendered oppression asserts itself in sex discrimination, in discrimination against trans* people, in gendered harassment and \#metoo - we must bring a critical perspective to bear on current equity policy practices.
\end{abstract}

\section{ARTICLE HISTORY}

Received 27 April 2018

Accepted 5 January 2019

\section{KEYWORDS}

Title IX; public policy; athletics; sex discrimination; sex segregation; transgender politics

\section{Politics of gender inequality: what's the problem?}

In June 2012, President Barack Obama offered multiple public statements which celebrated the 40th anniversary of Title IX of the Education Amendments of 1972, the sex non-discrimination policy which dramatically altered American educational institutions and their contingent athletic programs. ${ }^{1}$ President Obama - whose daughters are both young athletes - openly lauded public policy, suggesting that it "helped to make our society more equal in general" (Compton 2012). This positive narrative of policy success was widely promulgated in the media (Whiteside and Roessner 2018) and may, therefore, appear uncontroversial. Scholars from various disciplines demonstrate a plethora of positive impacts of policy implementation, including women's improved access to higher education (Rose 2018), a nearly 12-fold increase in high school athletic opportunities for girls since the early 1970s (NCAA 2017b), women's subsequent

CONTACT Elizabeth A. Sharrow sharrow@polsci.umass.edu Department of Political Science, Department of History, University of Massachusetts Amherst, 200 Hicks Way, Amherst, MA 01003, USA 
increased labor force participation (Stevenson 2010) and improved long-term independence and health (Clarke and Ayres 2014; Kaestner and Xu 2010).

Yet upon deeper reflection, President Obama's public celebration of Title IX - particularly as it is applied to athletic programs in American high schools, colleges, and universities - is peculiar. "Equality," under Title IX in the realm of sports, exists through segregated boy's versus girl's, and men's versus women's athletic teams. The paucity of sex integrated athletic teams in interscholastic and intercollegiate athletics is not merely due to custom and tradition. The practice of sex segregation in athletics is "coerced" (McDonagh and Pappano 2007) under Title IX's policy design. Thus, Obama's comments were not merely applauding the athletic girls and women who benefit from policy; the first Black American president was openly and proudly celebrating the widespread athletic practice of separate but equal.

Separate but ostensibly equal segregated athletic teams for men and boys versus women and girls are pervasive in American high schools and colleges. ${ }^{2}$ Simultaneously, Title IX remains extremely popular and is commonly framed as a pre-eminent success of modern American feminist movements (Whiteside and Roessner 2018). Political elites as dissimilar as Ralph Nader (2003) and Sarah Palin (2007) join the majority of average Americans who express increasingly high levels of support for the law as applied to athletics, in particular (YouGov 2017). ${ }^{3}$ Our public narrative around Title IX suggests, in short, that while policy remains unevenly implemented across athletic departments such that men and boys persistently enjoy greater athletic participation opportunities (e.g., Yanus and O'Connor 2016), the political battle towards achieving equality should focus on better enforcing the policy as currently designed. ${ }^{4}$ Neither the public nor our political leadership openly grapples with the potential impacts of segregation as a non-discriminatory solution. ${ }^{5}$ Over 45 years after Congress passed Title IX, what are the consequences of the divergent, yet concurrent approaches of sex segregation in athletics, and sex integration in classrooms for the broader politics of sex and gender? ${ }^{6}$ How does policy design shape how we think about sex-based inequality?

This article begins from the premise that sex segregated athletics in American colleges and high schools must be understood in the broader context of public policy. When sports, under Title IX, are placed in contrast to policy implementation in classroom spaces, policy design for athletics can be rendered curious instead of natural. Core to this analysis is a close read of Title IX's central non-discrimination clause, "on the basis of sex," through which policymakers are tasked with crafting equal educational institutions and opportunities for women and men. The meaning of "sex," rather than existing as a given, requires a definition. ${ }^{7}$ Alongside gender and queer theorists who have long argued that the meanings of "sex" and "gender" are fashioned by our social and medical institutions (e.g., Butler 1993; Fausto-Sterling 2000), this article examines how sex non-discrimination policy design mobilizes that constitutive task through political institutions, and with what consequences.

\section{Against the grain of policy success: Title IX's gendered paradox}

My analysis illustrates how Title IX's policy design establishes the meaning of sex built on a gendered paradox. Policy design conceptualizes women and men as (1) distinctive types of people, defined as such through a binary notion of "sex," who are (2) both "the same" 
(in classrooms, where policy treats them similarly, integrating without regard to sex) and "different" (in sports, where policy segregates them on to separate athletic teams by virtue of sex) under the aegis of non-discrimination policy. On sports teams, but not in classrooms, Title IX's implementation guidelines divide girls and women from men and boys. Policy design defines sex as a binary category for the purposes of competitive athletics, mobilizing this categorical definition to implement the practice of "separate but equal." Through the extant policy guidelines, sex serves as both the object of focus for policy (i.e., the identity category in classrooms on which differential treatment is prohibited) and the organizational category inherent to implementing it (i.e., the category through which some bodies are differentially treated in sports). Policy design within Title IX thus invokes an embodied, binary definition of sex for athletics, but not classrooms, knitting civil rights policy to binary notions about sexual difference and biology.

Several consequences follow from this framework for thinking about Title IX. The paradox suggested in policy design sanctions, rather than challenges, pernicious stereotypes about women's inferiority. This means that for all that Title IX's implementation has achieved in increasing opportunity for women, it has simultaneously undermined the goals of full gender equality. Segregation is premised on the perceived "need" for women to be protected from men and their purportedly stronger, faster, larger bodies, in order to achieve their full, competitive athletic potential. As political theorist Iris Marion Young elucidates, this encodes and transmits a confounding message: "Feminine bodily existence is an inhibited intentionality, which simultaneously reaches toward a projected end with an 'I can' and withholds its full bodily commitment to that end in a selfimposed 'I cannot'” (1980, 145).

This paradox then produces other "spillover" consequences within, and stretching beyond, Title IX's policy domain. Chiefly, it reinforces the idea of a sex binary. Dichotomous understandings of sex are flawed scientifically and injurious both to transgender, intersex, non-binary, and gender non-conforming people (hereafter, "trans"”) as well as - albeit in different ways - to cisgender women. ${ }^{8}$ The paradox embedded within Title IX fuels a host of intractable and on-going tensions which help to sediment, rather than dismantle, many of the unresolved gendered hierarchies at the core of equity policy battles, from gendered equality at work to youth sports. ${ }^{9}$ Policy suppresses opportunities for direct competition between women and men while reifying the idea that women need to be "protected" from men. In a world grappling with the legacies of male enclaves in a sex integrated world (see Menarndt 2018 with implications for \#metoo), and a young generation increasingly apt to challenge the meanings of gender (Meadow 2018), identifying the spillover and interconnections between sports and other venues is increasingly urgent.

Although I adopt this critical posture, I do not argue that Title IX's impacts have been purely negative. A host of studies illustrate how public policy has positively impacted women's education, athletic opportunities, and long-term life outcomes, on average (e.g., Staurowsky et al. 2015). ${ }^{10}$ However, my analysis cautions that current policy design contains inherent structural limitations. When we take seriously the gendered hierarchies "baked in" to policy design, there emerge more questions than answers about the role of Title IX in full gendered liberation. I suggest that we need to read against the grain of the progressive narrative of policy success to reorient the conversation about Title IX's 
legacy. I aim to diagnose the functional logics of on-going sex and gender oppression operating within the policy we often think is aimed to address them. In doing so, I point toward fresh possibilities for sex equity policy.

In order to delineate my critical perspective, this article unfolds in four parts. First, I demarcate the contradictory logic of sex integration versus sex segregation embedded in policy design. Next, I problematize it. This critical perspective enables my analyses of its spillover effects. I conclude by reflecting on how scholars and policymakers might proceed with this conversation going forward.

\section{Policy design and separation by sex: classrooms versus athletics}

One element of the extensive U.S. civil rights policy apparatus, Title IX became law as part of the 1972 Education Amendments (Rose 2018). The gendered paradox at the crux of policy emerged in the early 1970s when feminist activists successfully politicized the differential and exclusionary treatment of women in education as a newly acknowledged form of discrimination "on the basis of sex." Activists drew on long traditions of feminist critique (Cott 1987), framing educational institutions as a breeding ground for sexist exclusions of women from public life (Evans 2010). Their main objective was to end biased treatment of women and girls in education (Rose 2018); sports were absent from the legislative language and only emerged as a target of sustained discussion when implementation deliberations began (Sharrow 2017).

Policy discussions about environments for classroom learning generally targeted means for integrating girls and women into the androcentric realm of education (Fishel and Pottker 1977). The final guidelines which stipulate policy design explicitly address "access to class and schools" (herein: "classrooms") independently from athletics. With regard to classroom spaces, guidelines specify, "a recipient shall not provide or otherwise carry out any of its education programs or activities separately on the basis of sex, or require or refuse participation therein by any of its students on the basis of sex" [34 CFR 106.34(a)]. Two exceptions to requisite integration are named, (1) "contact sports" in physical education class which involves bodily contact (including wrestling, boxing, rugby, ice hockey, football, basketball) and (2) courses on human sexuality. Integration is required for education programs pertaining to health, general physical education, industrial, business, vocational, or technical education, home economics, and music. In contrast, athletics "may operate or sponsor separate teams for members of each sex where selection for such teams is based upon competitive skill or the activity involved is a contact sport" at both the intercollegiate and interscholastic levels [34 CFR 106.41(b)]. Additionally, the Office for Civil Rights (OCR) issued a policy interpretation focused specifically on intercollegiate athletics (OCR 1979). ${ }^{11}$

At the core of these divergent approaches to non-discrimination sits the operative definition of "sex." In classrooms, policy design aims to make sex irrelevant as a category for learning. ${ }^{12}$ In sports, sex is the only category that matters. To justify these "separate but equal" athletic practices, policy design requires a definition of sex that is rigid and "essential." ${ }^{\prime 3}$ Sex, as invoked for implementation in athletics, is an immutable attribute of the human body. ${ }^{14}$ It is central to policy implementation in sports but not in classrooms and thus has - unexpectedly - reduced complex functions of human biology, which are themselves embedded in an inequitable social world, to a gendered binary. 


\section{Policy implementation details for intercollegiate athletics: separation paradigm}

This gendered binary is encoded in the granular details of policy design. The 1979 guidelines for intercollegiate athletics instruct schools to comply with an equal opportunity paradigm, under which teams are allowed to be sex "separate"; notably, no such detailed guidelines delineate the practice of classroom integration. ${ }^{15}$ Schools must demonstrate that their athletic opportunities for men and women are "substantially proportional" to the enrollment of their undergraduate student population. ${ }^{16}$ If $51 \%$ of the overall undergraduate student body is comprised of women, Title IX's policy guidelines suggest that $51 \%$ of the athletic opportunities (measured by the roster count of each sport on the first day of intra-squad competition by each team) also be available to women. ${ }^{17}$

These guidelines do not strictly prohibit the integration of women and men on the same team. Schools are instructed that the "regulation does not require institutions to integrate their teams nor to provide exactly the same choice of sports to men and women" (OCR 1979). However, in the case of teams requiring some "competitive skill" (ostensibly referring to all institutionally-funded, varsity-level athletic teams), "separate teams for members of each sex" are allowed. Contingently, if an institution offers a sport only to "members of one sex," it must allow the excluded "sex" to try out for the team in some, but not all circumstances. ${ }^{18}$

In many sports, where there exists a men's but not a women's competitive team, only a tryout is required, and even the tryout can be denied to women in so-called "contact sports." ${ }^{\prime 9}$ The de facto result of these regulations is that historically dominant "men's" sports have been unaffected by the policy designed to include women into sporting domains. ${ }^{20}$ Football, in particular, has been essentially unrestricted under Title IX, and very few women have been allowed access to (presumed "men's") football teams (Brake 2010; Hoye 2013). These enduring male-centered practices in sports - examples of what Sandra Bem names "androcentrism" - buttress the idea that sports are naturally men's domain and that the paradigmatic athlete is male (Bem 1993). The separate domains established by policy design largely serve to retain "men's" sports for "male" participants and, because Title IX does not require sex equality in spending practices, they have enabled widespread, nearly $\$ 2$-to- $\$ 1$ expenditure disparities which dramatically favor men athletes in the largest athletic programs (NCAA 2017b).

This, alongside the tryout exclusions for women's participation in "men's" contact sports, illustrates how sex segregation is both premised on, and reproduces a gendered hierarchy. The fear of "contact" suggests (1) a hetero-centric anxiety about physical proximity and intimacy between women and men (but not between same-sex competitors) ${ }^{21}$ and (2) that women need "protection" from men's (presumed to be stronger) physicality during training and competition. These practices authorize pernicious ideas about women's physical inferiority and heterosexist assumptions about the role that sexuality plays in bodily contact between competitors (e.g., that sexualized contact can be prevented by segregated teams and locker rooms). Segregation diminishes the egalitarian potential of integrated practice, suggested by evidence of diminished sexist attitudes among men and boys who train and compete with girls and women (Anderson 2008). It also it co-articulates with homophobia to introduce trepidation around the role that homosocial spaces play in the socialization of girls and boys. ${ }^{22}$ 
Procedurally, sex integration is never required in athletic settings under Title IX, and segregation, although not strictly compulsory, is - as McDonagh and Pappano (2007) argue - a "coercive" policy practice. If a school hosts both a "men's" and a "women's" team, women - regardless of skill - are generally not allowed to compete in the "men's" division (Brake 2010). ${ }^{23}$ At the high school level, some states even prevent girls who merely train with boys from ever again competing in the "girl's" division (Weil 2015). In the absence of designated teams for both sexes, women may be allowed to try-out for the "men's" team using the same metrics as male candidates for the team. There are no particular rules to the content of such a try-out, only that it must be internally consistent among both women and men candidates for the team. For "men's" teams that are designated under Title IX as "contact sports," even this try-out can be denied to women. $^{24}$

\section{From policy to problem: thinking with feminist legacies}

The implications of this policy design require close attention. Title IX makes meaning of biological sex through segregatory practices, implicitly replicating what Kessler and McKenna (1978) call the "incorrigible proposition" of sex difference (i.e., that sex difference exists outside of our social ideas about it). Policy invokes social ideas about binary sex as the prima facie category of distinction in the establishment of athletic teams, despite mounting evidence from science and biology, and intensifying critique from gender and queer theory, that "sex" is neither a coherent nor a binary category (Fine 2010; JordanYoung 2010; Karkazis et al. 2012). ${ }^{25}$ Several generations of social scientists, theorists, and brain scientists scrutinize the operation of such "natural attitudes" (Kessler and McKenna 1978) to suggest that "gender can be reconceptualized as an 'effect' rather than a mere fact, something that requires explanation rather than something that explains the social world" (Jordan-Young 2010, 258). Increasingly, scholars argue that our understanding of "sex," rather than existing as a pre-gendered, biological binary, is, like gender, constituted by social ideas (Butler 1990; Fausto-Sterling 2000; Karkazis et al. 2012). ${ }^{26}$ "Sex," like "gender," is best understood as a concept used to capture our imagined ideas about an embodied binary (male/female) than the existence of an actual sex binary itself. Yet these ideas about a male/female binary are implicit in our social and political structures and discourse, including Title IX's policy design itself. Although our understanding of "gender identity" (i.e., the psychological dimension of sex-based identification) as distinctive from sex-assigned-at-birth (i.e., the categorical designation of male/female on birth certificates) has evolved significantly since the passage of policy (see also Meyerowitz 2004), policy design in Title IX, particularly with regard to the separation paradigm, has not (Balingit 2018). Public policy plays an important role in naturalizing our (fraught and problematic) understanding of sex-as-a-binary through its use of sex segregated sports. $^{27}$

Policy design in Title IX suggests that "sex" is an immutable physical characteristic of bodies. By segregating when matters of physicality are most salient (in competitive athletics), and integrating when intellectual concerns dominate, policy design suggests that women and men are categorically, biologically different from one another. Policy design operates as a powerful engine for re-naturalizing the idea of sex difference, and stabilizing, rather than contesting, androcentric gender hierarchies. 


\section{Can separate be equal? Extant critiques of Title IX and segregation}

Several common arguments in favor of sex segregated sports endure including that (1) men and women have different physical capacities which leave women unable to compete with men, (2) segregation ensures that women need not compete with men over one set of shared opportunities (an argument which implies, again, that if/when women did compete with men, they would/will inevitably lose), and (3) that women and men do not desire to compete against each other (see Leong 2018; McDonagh and Pappano 2007; Milner and Braddock 2016). Each of these arguments engages sex essentialized logics which assume that "men" and "women" are coherent and mutually exclusive categories and that all women, by virtue of being women, are weaker and slower than all men. Such arguments in support of segregation have their historical roots both in patriarchal, sexist logics and in feminist debates in the early 1970s when women's exclusion from competitive athletics was most pronounced (see Cahn 1995 on the history of women in sport). In the absence of evidence about women's latent athletic potential or competitive desire, the majority of feminist activists in the 1970s authorized the segregationist strategy (e.g., PSEW 1974 for original feminist debate; Sharrow 2017 for historical context). Neither policymakers nor Title IX's activist proponents have seriously returned to the question of integrated athletics, effectively de-problematizing the approach over time.

Many scholars of sport, legal studies, and Title IX delineate their concerns about the impacts of sex segregation. While some legal scholars suggest that sex segregation is "the most promising feminist strategy" (Brake 2010, 38), even those who support it must grapple with its costs. In a book which most recently reinvigorated the debate over sex segregation, McDonagh and Pappano (2007) question whether the physiology of men and women athletes fundamentally justifies the practice of sex segregation within Title IX, delineating many examples where women's physical performance is equal to, or better than men's. Their argument critiques the 1979 policy guidelines insofar as the guidelines imply that segregation prevents women from being physically hurt or exposed to "unfair" competition. They convincingly argue that rather than merely reflecting sex difference between "male" and "female" athletes, sex segregation amplifies foundational sexist ideas. ${ }^{28}$ This socially constructed binary is central to falsely understanding some sports - and segregated teams - as either "men's" (e.g., football or baseball) or "women's" (e.g., softball or field hockey) domains, leading to the problematic exclusion of women from supposedly "men's" sports (Hoye 2013; Ring 2009). Such reasoning recalls Judith Lorber's (1993) argument that "biology is ideology" (i.e., that gender, rather than biology, constructs social bodies to be different and unequal), and helps to situate the problem of segregation in the long-standing feminist critique of gendered binaries and sex essentialism (Bem 1993; Dietz 2003). ${ }^{29}$

The problematics of athletic segregation are intensely evident in the exclusionary treatment of trans ${ }^{*}$ athletes who confront a complicated matrix of standards for athletic participation at the interscholastic, collegiate, and elite levels in a segregated system (Acklin 2017; Buzuvis 2011, 2013; Davis 2017; Smith 2017). "Sex testing" of elite female athletes, an invasive practice which has taken multiple forms (Pieper 2016), now patrols testosterone levels of ciswomen who aim to compete in some track events. ${ }^{30}$ Elite-driven attempts to stabilize sex segregated competition directly engage a biologic notion of "sex" encoded through hormones, and are most restrictive for intersex and gender non-conforming 
athletes, particularly women of color (Karkazis and Jordan-Young 2018). Interscholastic and intercollegiate athletics governed by Title IX borrow from signals transmitted by international sports governing bodies (e.g., the International Olympic Committee) in maintaining policy design, even without "testing" participant sex. ${ }^{31}$ Instead, NCAA and state high school association policies (not federal law) delineate the specific rules for transgender athletes to "jump" categories (see Buzuvis 2011) in order to maintain eligibility in a sex segregated system. ${ }^{32}$ Yet trans ${ }^{\star}$ athletes have been more apt to seek annexation under the segregated system of Title IX rather than to challenge the federal law which reifies sex difference itself. This is most impactful for transwomen who seek inclusion in the "women's" category but are haunted by androcentric hierarchies that imbue natal hormones with enduring athletic power. Even in a system designed to maximize "opportunity," these logics harm both ciswomen (whose bodies are pre-supposed as "too weak" for integrated competition with men) and transwomen (whose bodies, even after medical transition(s), are thought to be "too strong" to compete fairly with ciswomen). ${ }^{33}$

Thus, the practical and ideological harms of segregation for cisgender women are more closely aligned with trans ${ }^{\star}$ athletes than it may seem. Gendered binaries policed thru ideas about embodied sex, in addition to forcing a categorical imperative onto fluid genders, also reifies the athletic hierarchy that favors cismen above all other identities. Cismen encounter virtually no surveillance in the tradition of maintaining "men's" teams and competitive categories, while ciswomen and trans ${ }^{\star}$ athletes can endure significant scrutiny in their quest to retain eligibility in "women's" competition. Transgender athletes (particularly transwomen) may be rendered ineligible to compete in both their pre- and post-transition division; the maintenance of sex categories is the foundation of such harms. Transmen are more readily incorporated into "men's" teams because of other sexist logics which ascribe being assigned "female" at birth as a marker of inferiority which does not present a competitive advantage vis-à-vis cismen competitors.

Accordingly, the problem is not merely that trans ${ }^{\star}$ athletes may not find inclusion in a segregated system, although this is a problem worthy of concern. ${ }^{34}$ The problems for trans ${ }^{*}$ inclusion should direct our attention back to purportedly "non-discriminatory" solutions "on the basis of sex." Certainly, the creation and maintenance of sex-based competitive categories for ciswomen under Title IX have more positively benefited average cis athletes, but such teams have neither served to up-end male dominance in sports nor provided non-discriminatory opportunities for trans ${ }^{\star}$ athletes. $^{35}$ Policy practices secure teams and competitive opportunities for women assigned "female" at birth, but do such teams provide the best opportunities to upend gendered stereotypes of "women's" inferiority? And how do practices which value and protect both maleness and male enclaves inform our societal conversations about the gendered order? The next section considers the ramifications of Title IX for these questions.

\section{Spillover harms: a call to scholars of gender and policy}

The gendered paradox - men and women are "the same" while also "different" - within policy design illustrates our persistent ambivalence toward the meanings of sex and gender within institutions targeted by non-discrimination policy. In this final section, I develop the implications of my argument about the tensions in Title IX's policy design. These "spillover effects" of authorizing sex segregation in such a politically popular and normatively 
valued policy suggest reasons to question the operation of segregation both within and beyond Title IX's domain.

Scholars of American politics indicate cause for concern in the on-going project of integrating women (and, though lesser discussed, trans ${ }^{\star}$ people) into the institutions of American government. ${ }^{36}$ Women of color, women with disabilities, LGBTQIA women, and other intersectionally marginalized subgroups struggle for political recognition (Strolovitch 2007). Women and girls now enjoy greater educational attainment and workforce participation than ever before due to the implementation of policies like Title IX, and Title VII of the Civil Rights Act (CRA) of $1964 .{ }^{37}$ However, contrary to women's purportedly equal access to education, they face a complicated terrain upon entering the workforce defined by limited access to parental leave and health care, an entrenched wage gap, and a virtually impenetrable glass ceiling (Grossman 2016). Americans remain gripped by an age-old conundrum across multiple venues - grappling with whether women should be treated "the same" or "as different from" men - over how to conceive of and best address "women's interests" at school, at work, and in politics.

Various factors account for the gaps between the promise of policy and the persistent "intersectional" gender inequalities in the status quo. ${ }^{38}$ Public policy aimed at protecting women and girls from discrimination has arisen from complex movement demands (Costain 1981; Goss 2012). Even after the passage of non-discrimination laws, battles over de jure enforcement are often prolonged (Grossman 2016; Thomas 2016). In general, the courts have provided only a partial pathway to recompense for sex discriminatory treatment (Edelman 2016). In short, and as political theorists have contended for decades: gendered hierarchies remain fundamental to the organization of the American political system (Dietz 2003; Ritter 2006). Yet scholarship which draws critical attention to policy designed to address these issues remains strikingly limited.

We live in confounding times when the ideology of sexism is under intensive critique, yet misogyny seems resurgent. As philosopher Kate Manne reminds us, "sexism often works by naturalizing sex differences, in order to justify patriarchal arrangements, by making them seem inevitable, or portraying people trying to resist them as fighting a losing battle" (Manne 2017, 79). Misogyny, in contrast, "upholds the social norms of patriarchies by policing and patrolling them" (Manne 2017, 88). Although we rarely look to Title IX as a domain in which misogyny may draw on sexist logics to hinder the liberation of trans ${ }^{\star}$ people and ciswomen and girls, my critique as applied to reading recent events suggest that we should.

During the summer of 2017, young girls in Madison, WI, and Omaha, NE experienced harassment and exclusion from competition in their youth soccer leagues because their short haircuts made them look "too much" like boys (Koss 2017; Mele 2017). The same summer, a New York Times survey found that Americans indicate substantial levels of discomfort with the sex integrated workplace (Miller 2017) only one week after the Women's Sports Foundation - the preeminent women's sports advocacy organization in the country - released a national poll indicating overwhelming support for Title IX (YouGov 2017). These seemingly disparate stories each reveal an insidious implication from the problem of sex segregation.

The events in Wisconsin and Nebraska within girls' soccer leagues illustrate how the ideology of gendered hierarchies "baked in" to sport diminishes, rather than expands the liberatory potential of Title IX. Girls on these teams fashioned their hair in short 
styles as an homage to U.S. National Women's Soccer Team members Megan Rapinoe and Abby Wambach. The haircuts were read by the parents of competitors as "too masculine," and the young girls were subjected to accusations that they were masquerading "as boys" in a girl's league (Koss 2017; Mele 2017). Such accusations echo those lobbed at Caster Semenya and Dutee Chand, elite runners targeted by hyperandrogenism policy (Karkazis and Jordan-Young 2018).

What do such anxieties suggest about the conditions of "equality" available under a segregated system? For one, they illustrate that when we authorize segregation, we invite gendered surveillance of participants on girls and women's teams. Who are the "real" women and girls? How will we know them as such? This surveillance serves to authorize, rather than challenge, traditional gender expectations about "proper" gender presentation as fused to the physical body, illustrated by the accusations that short-haired athletes are not "really girls." In Wisconsin, the parents were asked to produce their children's birth certificates to authenticate the sex of their child. That natal birth was assumed to verify inclusion (or exclusion, had the documents not "revealed" the proper sex) exposes the thorough permeation of athletics by embodied judgments of sex.

The logic under which parents sought to invoke segregated athletics to exclude shorthaired people also reveals the convenience of segregation for authorizing transphobia and homophobia. Homophobia in segregated women's athletics is a perennial concern (e.g., Cahn 1995) which is especially evident in such appraisals of young girls who emulate out-lesbians like Rapinoe and Wambach. Homosocial spaces "protect" girls and women from purportedly stronger men and boys, but not from the fear that athleticism shelters lesbianism. The potential exclusion of "masculine" girls hints at a how transphobia, coarticulating with homophobia, can swiftly police the "proper" participants on "girl's" teams. The policing of masculine gender presentation on a "girl's" team reveals how narrowly defined the category of "girl" (or "woman") in segregated teams can be. With sexist logics guiding segregatory practice, therein lurks anxiety that gender non-normativity is poised to unravel the binary category of sex. It also suggests that the logics of strict segregation easily permeate youth sports. ${ }^{39}$ Title IX's authority does not extend to youth athletics, but its categorical logics do.

Girl and women athletes under a sex segregated system always run the risk of appearing (or developing skills that make them) "too good" for the "female" teams, but without recourse to compete elsewhere. ${ }^{40}$ Finally, the actual accomplishments of women athletes are both occluded by their lack of opportunity to demonstrably out-perform men in head-to-head competition, and they are interpreted by many as inherently less impressive than the accomplishments of top-performing men. ${ }^{41}$ In short, the policy legacies of Title IX have both reproduced hierarchies that non-discrimination policy aimed to denounce, and created additional problems which plague both its purported beneficiaries, and girls and women more generally.

Although Title IX is not itself responsible for all persistent gendered inequalities, the ideology of sex segregation sanctions significant ambivalence toward the questions of how and where women and men should directly grapple with shared space. This was recently illustrated in a New York Times poll (reported on the front page of the paper under the headline: "When Jobs Put Sexes Together, Worker's Cringe") regarding the impact of sex integration in the workplace (Miller 2017). The poll, fielded after a 2002 
interview with Vice President Mike Pence resurfaced in March 2017 which featured his statement that he "never eats alone with a woman who isn't his wife," found that:

Many men and women are wary of a range of one-on-one situations ... Around a quarter think private work meetings with colleagues of the opposite sex are inappropriate. Nearly two-thirds say people should take extra caution around members of the opposite sex at work. A majority of women, and nearly half of men, say it's unacceptable to have dinner or drinks alone with someone of the opposite sex other than their spouse. (Miller 2017)

In short, American adults remain uncomfortable with the sex integrated environment of the American workforce.

On its face, this poll should be interpreted advisedly. For example, the pollsters did not distinguish among the reasons that integration may be considered "inappropriate," including among women who fear that sexual harassment may be more likely when left alone with male co-workers - a point underscored by "\#metoo" activism. However, it illustrates another pernicious impact of the ideology of sex segregation.

The ideology of women's "difference," when authorized anywhere is available anywhere to justify exclusion, disparate treatment, and sexual harassment. Over the past halfcentury, at male-only institutions (Strum 2004) and in the U.S. military (MacKenzie 2015), feminist and civil rights advocates have fought mightily toward women's full inclusion in historically male enclaves. Similar battles are waged to create an integrated workplace under Title VII (Turk 2016). Thus, the resurgence of ambivalence, and even skepticism towards integration should cause some alarm.

Male-enclaves - protected in athletics under Title IX while they have been outmoded elsewhere - are perceived to both profoundly socialize men into proper masculinity, develop their "leadership skills," and to do so in the absence of women (e.g., Messner 2011). No wonder, then, that Americans continue to express apprehension about the integrated workplace. In a society that celebrates the paradox of segregation in a popular public policy, even as the logics of that policy promote the ideology of sex essentialized difference, we are apt to remain perplexed. The scenarios in both youth soccer and the integrated workplace underscore - in different ways - that we remain trapped in an unresolved dispute over whether girls and boys, or men and women, can share the same social spaces and be treated equally - or safely, as the resurgence of attention to sexual harassment and assault reminds us - if and when they do.

In the early twenty-first century, Americans remain committed to public policies (foremost among them, Title IX) that we believe will make sex discrimination a relic of the past, even as we repeatedly encounter evidence which demonstrates that at school, at work, and at play, policy has only partially produced such an outcome. Not only must we reckon with the legacies of policy debate as we confront the possibilities for future alternatives, but we must also consider how the logics embedded in a policy which is often cited as an example of success nevertheless provides problematic models for parallel, unresolved policy areas.

\section{Conclusions and future directions}

Over the past 45 years, there have been two distinct sets of practices and ideologies set in motion by policy implementation. On the one hand, policy has forced institutions to cease unilaterally denying women and girls access to competitive athletics. Increased 
opportunities mean that now eighty-seven percent of Americans believe that sports are "equally important" for girls and boys (YouGov 2017), and current college athletes overwhelmingly support sex equitable athletics systems (Druckman, Rothschild, and Sharrow 2018). Policy has created the conditions for women and girls to develop physical skills which directly defy the presupposition that they are incapable of sports. With this, policy has shepherded evolutions to the gendered expectations about physicality, allowing women to pursue pathways for achieving their physical potential.

But simultaneously, sex segregated sports have suppressed evidence of women's increased speed, strength, and achievement vis-à-vis men. We rarely see post-adolescent athletes compete or train in integrated settings, and thus we seldom confront the challenge posed by women's actual capacities to the reigning order of sports. We are slow to acknowledge, for example, that elite women marathon runners, whose fastest times have improved more rapidly than have men's, are faster than many men also entered into the "elite" categories. ${ }^{42}$ Because we name a "women's champion" in such sex integrated competitions, for example, the sex segregated logic for all sports allows critics to discount the victory of the fastest women over the preponderance of men. The "women's champion" can claim victory of all women, while the "men's champion" is presumed to claim victory over all. Women's accomplishments are conditioned on being merely "female athletes," while men's achievements in racing sports stand for the supremacy of all men.

Unexpectedly, these issues are enabled within the public policy aimed at addressing sex inequity. Title IX exalts these practices that serve to obscure the accomplishments of cisgender women and police or exclude trans ${ }^{\star}$ people, even as public policy remains revered by many political leaders and in popular discourse. Implementation has so normalized the practice of segregation that it simultaneously obscures its own harms and the pernicious spillover logics which inhibit women's full liberation. Yet policy once made can be renegotiated. Evidence suggests that women athletes, rather than existing as a latent activist group, perceive implementation problems in policy and are prepared to politically mobilize around Title IX (Druckman, Rothschild, and Sharrow 2018). ${ }^{43}$ Among elite athletes, the recent announcement of hyperandrogenism policies for some events in track and field were met with athlete protest (Fryer 2018). Such mobilization among policy beneficiaries and their allies will likely be necessary to advocate for revisions to the status quo. However, the first step in achieving such a political movement is denaturalizing this paradox in policy design.

After four decades of policy implementation, scholars - if not yet interest groups or policymakers - posit the need for revisions to Title IX. Several argue for a new two-tiered system, with open-access to "men's" teams for women, and closed access to men for "women's" teams - what McDonagh and Pappano (2007) call "voluntary" segregation. ${ }^{44}$ Others suggest that sports should be subjected to the same "intermediate" legal scrutiny as occurs in other sex- and gender-based contexts (Leong 2018), and many agree that the ban on sex integration in "contact sports" must end (e.g., Bell 2016; Caggiano 2010; Sangree 2000). Some advocate that athletics should be entirely free of sex-based classifications (George 2002).

My suggestions for future directions align most closely with those scholars who center the radical possibilities available when men's teams become more "open," even if women's teams should, at least in the near-term, remain "closed" to cismen (McDonagh and 
Pappano 2007; Milner and Braddock 2016). My critical perspective on the gendered paradox in policy design, and in light of my argument that gendered hierarchies promoted through segregation both harm women and trans* folks while enabling logics of male supremacy, lead to the possibility for several specific changes. Because "men's" teams continue to be the more highly resourced and valued, I propose that the near-term should be focused on opening men's programs to more women athletes. Although my long-term hope is that athletic competition can be organized more diversely - e.g., around weight class, body size, or participant skill level - depending on the requirements of the sport rather than the category of sex, the initial target of critique ought to be the arenas were the ideology of male superiority is most naturalized. Namely, the "contact sports" distinction needs to be eliminated. Doing so would end the chief gatekeeping mechanism preventing women from the opportunity to "try out" for a "men's" team. Because the policy language is loaded with biased assumptions about men's physical superiority, revising it would ensure that girls and women with the skills and desire to challenge such norms are not impeded by the myth that "separate" is always equal. This would also provide the most ambitious "female athletes" the opportunities to train and compete with men, to enjoy the resources more widely available to men's programs, and to directly challenge on the terms of their sport the notions that sex-difference determines competitive outcomes. Allowing women to compete on "men's" teams even when a similar team exists "for women" would enable competitors and spectators alike to observe and grapple with the significant overlap in athletic performance between women and men, much like required classroom integration has done for ideas about women's intellectual capacities. Ending strict segregation also lessens the complicated exclusions for trans ${ }^{\star}$ athletes, whose opportunities will broaden as we loosen our attachment to the idea that sex inheres in bodies and is largely synonymous with athletic prowess.

Finally, ensuring that male enclaves in sport are challenged, rather than protected, also provides pathways for integrated socialization which ensure that neither girls nor boys learn the logics of essentialism as if they are the "natural" order (see also Anderson 2008). This would also revisit lesser-known, historical policy debates. Athletic integration, after a period of investment in righting the historical exclusions from access to sports and athletic training experienced by women before Title IX, was supported by some feminist interest groups in the 1970s (Sharrow 2017). Aggressively pursuing partial integration, currently used to address some intractable male enclaves in the workplace (Stevens 2018), would ensure that the best girls and women have every opportunity for highlevel competition and training without abruptly forcing integration on all athletes. Perhaps in time, more widespread integration of teams can seem less preposterous. At present, sex segregation has not produced non-hierarchical outcomes, and without some critical discourse, women and trans ${ }^{\star}$ people are inhibited in their abilities to challenge their oppression. Engaging the critique of segregated spaces will be fundamental to any strategy which tackles the most pressing problems in Title IX, and broader gender politics, in the coming years.

\section{Notes}

1. Signed into law on June 23, 1972, Title IX declares: "No person shall, on the basis of sex, be excluded from participation in, denied benefits of, or be subjected to discrimination under 
any educational program or activity receiving Federal financial assistance” (20 U.S.C. \$1681). It applies to all institutions receiving federal funding, with a few exemptions: single-sex educational institutions, private schools controlled by religious organizations, military academies, fraternities or sororities, and some specific auxiliary programs (i.e., Boys and Girls State programs, the Boy Scouts and Girl Scouts, etc.), and private school admissions decisions (20 U.S.C. \$1681-1688). Intercollegiate/interscholastic athletic programs are considered relevant under Title IX because they are component programs of the larger university or college.

2. Statistics on sex integrated athletic teams are scarce, although they are much more common in youth sports which fall outside of Title IX's purview. At the college level, sex integration is so uncommon that the National Collegiate Athletic Association (NCAA) does not report statistics on sex integrated teams. Likewise, sex segregated competition in elite sport is ubiquitous and, in contrast to collegiate and high school athletics, maintained through a long history of "sex testing" and "gender verification" of athletes competing in the women's category (see Pieper 2016).

3. Title IX has also become a vehicle to address campus sexual climate and assault (see also Doyle 2015; Reynolds 2018).

4. Policy history is also marked by critique from men athletes who participate in sports like gymnastics and wrestling (Suggs 2005). Although men's opportunities have increased overall and men continue to enjoy greater numbers of participation opportunities, some lower-profile men's sports have experienced significant cuts to funding and opportunities while men's football budgets and opportunities have ballooned (NCAA 2017a).

5. This stands in stark contrast with the contentious battles around racial desegregation in American schools (e.g., Hochschild 1984).

6. I follow in the long tradition of feminist scholarship which argues that "gender" is the social expression of ideas around biology and that biologic notions about "sex," like "gender," are socially and ideologically constructed (e.g., Fausto-Sterling 2000; Jordan-Young 2010; Lorber 1993; Risman 2004). Kessler and McKenna (1978) note that gender is socially produced through "natural attitudes" about a male/female dichotomy. According to both feminist biologists (Fausto-Sterling 2000; Fine 2010, 2017; Jordan-Young 2010) and gender/queer theorists (Butler 1990, 1993), such attitudes are themselves socially constituted as a binary rather than a "fact" of nature. In the realm of politics, the terms sex and gender are increasingly used interchangeably (e.g., Title IX is commonly referred to as a "gender equality" policy despite its specific reference to only "sex") despite their particular and specific meanings and histories (Meyerowitz 2004; Repo 2016).

7. As I explore herein, policy employs a binary definition of "sex" which excludes transgender, intersex, non-binary, and gender non-conforming people. Although much debate transpired in the 1970s over interpretation and policy implementation (Edwards 2010; Rose 2018; Sharrow 2017), as I write this, the relationship between sex and gender-based discrimination in policy interpretation remains legally uneven. Whereas the Obama administration announced policy interpretations inclusive of non-discrimination protections for transgender students in 2016, the U.S. Department of Education under President Donald Trump rescinded such guidelines (Balingit 2018).

8. The term "trans" is meant to encompass a host of gender expressions and "signals greater inclusivity of new gender identities and expressions and better represents a broader community of individuals" (Tompkins 2014, 27).

9. The prevalence of \#metoo activism toward sexual harassment in the workplace and beyond illustrates the persistent struggle of women's treatment by men despite policy successes.

10. This narrative, while dominant, is not universally true. Women of color and girls from economically lower-resourced schools benefit less meaningfully from policy (e.g., Pickett, Dawkins, and Braddock 2012). For other intersectional critiques of policy, see Sharrow (2017).

11. These guidelines were produced through an overtly politicized process (Sharrow 2017), and remain largely unaltered as the contemporary mechanisms for policy implementation and enforcement. The athletics policy guidelines have been contested in litigation and clarified 
by the U.S. Department of Education primarily for reasons other than their treatment of sex segregation (Brake 2010; but see Love and Kelly 2011).

12. This approach reflects what a large literature on feminist legal theory calls "formal equality" which is guided by the idea that "men and women should be treated alike if they are similarly situated for purposes of the policy or practice that is being challenged" (Brake 2001, 25). Brake extensively delineates the formal equality paradigm in sex discrimination doctrine as applied through Title IX. This approach is widely discussed by legal scholars for its complex implications along debates of women and men's "sameness-versus-difference" (e.g., MacKinnon 1989). The formal equality paradigm is situated across multiple, secondwave, liberal feminist attempts to seek sex equality thru state institutions (see Dietz 2003; Turk 2016 for longer summary of feminist debate).

13. These sex essentialist approaches configure binary sex difference on the body and are thoroughly problematized by feminist theory (see Dietz 2003 for summary of how this "difference" approach diverges from other strands of feminist thought which argue for the importance of "women" as a political category).

14. This proposition applies what sociologist Michael Messner (2011) names "hard essentialism," which presumes bodily difference between women and men. Trans* inclusion, under Title IX, illustrates the rigidity of "sex" through the strict requirements that athletes jump categories from male to female, or vice versa (Buzuvis 2011).

15. Some feminist groups like the National Organization for Women (NOW) contested athletic segregation during policy development, although they eventually conceded to those who preferred separate teams for girls and women (Sharrow 2017).

16. Schools must also pursue equivalent treatment, benefits (i.e., athletic scholarships), and opportunities in

equipment and supplies; games and practice times; travel and per diem; coaching and academic tutoring; assignment and compensation of coaches and tutors; locker rooms, and practice and competitive facilities; medical and training facilities; housing and dining facilities; publicity; recruitment; and support services. (OCR 1979)

17. In practice, strict proportionality is not enforced but is instead evaluated under Title IX's "three-part test." The 1996 policy clarification memo clarifies that "part three of the threepart test permits evidence that [when] underrepresentation is caused not by discrimination but by lack of interest ... that underrepresentation alone is not the measure of discrimination" (OCR 1996). Schools are required to pursue, but not necessarily achieve, "proportionality" in opportunities and scholarships for women and men across their athletic program. If OCR (the U.S. Department of Education's unit charged with policy oversight) discerns that a school offers "substantially proportionate" athletic opportunities, any federal investigation into compliance with the law will not proceed. If the school fails this test, OCR will examine the institution's practices, evaluating whether it has a "history and continuing practice of program expansion which is demonstrably responsive to the developing interests and abilities of the members of [the underrepresented] sex" (OCR 1979). If the school is found to pass this "program expansion test" it will meet the participation requirement even though it failed the proportionality test. The third test of compliance is open to greater interpretation, allowing space for programs that have failed the "expansion" test. Owing its historic roots to the debates over whether women are equally "interested" in pursuing athletics (a sexist, but pervasive concern), policymakers resolved to allow schools to demonstrate that they had sufficiently met the student demand for athletic teams on their campus. Schools are directed to demonstrate that the athletic interests and abilities of "male and female students" must be "equally effectively accommodated." The methods for proving this have varied and are contested (Buzuvis 2006).

18. I qualify the term "sex" in order to underscore how policymakers assume without defining the inherent meaning of this category. 
19. "Contact sports" are defined in the 1979 guidelines as "boxing, wrestling, rugby, ice hockey, football, basketball and other sports the purpose or major activity of which involves bodily contact" (OCR 1979).

20. I demarcate the terms "men's" and "women's" teams in order to underscore and denaturalize the casual ways in which possessive language naturalizes segregated teams as belonging to "men" or "women" at the exclusion of each other.

21. Anxieties around intimacy are at once about privacy and sexual desire. Nominally, privacy concerns are more openly discussed regarding other athletic spaces such as locker rooms (see Sharrow 2017) where policy guidelines instruct schools to provide comparable but "separate toilet, locker room, and shower facilities on the basis of sex" (34 CFR 106.33). However, sex segregated restrooms produce other apprehensions, particularly for trans ${ }^{\star}$ people (Davis 2018).

22. Single-sex classroom spaces have been thoroughly contested (English 2016).

23. Sex segregated sports make it difficult to see, for example, that the times posted by decorated American swimmer Katie Ledecky at the 2017 NCAA Division I Women's Swimming Championships would have allowed her to qualify for competition in the "men's" championship.

24. The widespread and normative practice of women's exclusion from "contact sports" also impacts men's abilities to participate in "women's" teams, as men's legal claims to gain access to "women's" teams have systematically been denied (Love and Kelly 2011).

25. Scientists note that there are six distinct markers of what we call "sex" (including chromosomes, gonads, hormones, secondary sex characteristics, external and internal genitalia) which confound the idea of a strict binary; many individuals might be categorized as "male" by some markers, and "female" by others, a fact which is acutely problematic for some women athletes (Karkazis et al. 2012). The history of sex testing in elite athletics is illustrates the central issues, and has been particularly damaging to gender non-conforming women and intersex individuals, virtually all from the Global South (Karkazis and JordanYoung 2018; Pieper 2016).

26. Policy implementation remains impenetrable to such critiques as neither policymakers nor advocates target athletics as a civil rights domain that requires re-thinking: "women's sports" are promoted as a "separate but equal" solution and not a problem (see discussion in Brake 2010, chap. 1).

27. Other venues, including sex segregated public restrooms and prisons, also naturalize the idea of sex difference.

28. Other scholars echo this argument, placing segregation in sports in the context of problematic sex segregation in society elsewhere (e.g., Cohen 2011).

29. Feminist debates about the meanings of equality have a long history (Cott 1987; Goss 2012). The "sameness/difference" question regarding of sex non-discrimination is considered across many U.S. Supreme Court decisions regarding the interpretation of Title VII of the Civil Rights Act (Grossman 2016; Thomas 2016; Turk 2016), debates over an Equal Rights Amendment (Mansbridge 1986), scholarly debate regarding feminist legal theory (Brake 2001), and the 1996 U.S. v. Virginia (516 U.S. 515) case regarding single-sex admissions at the Virginia Military Institute (Strum 2004).

30. Activism coheres around attempts to end this focus on hormones, noting that it actively discriminates against intersex athletes (many of whom do not self-identify as such but who are, instead, revealed as possessing intersex traits by sporting officials who seek to confirm the eligibility of such athletes to compete in the "women's" event) in many damaging ways (Karkazis et al. 2012).

31. "Sex testing" polices women athletes but never men (Pieper 2016). This underscores my argument that women's bodies are the most targeted by segregation, even though Title IX does not employ "sex testing" to police the category of sex.

32. This, because "Transgender people create a profound category crisis for social institutions built on the idea that biological sex is both immutable and dichotomous" (Meadow 2010, 814). 
33. Whether that is the case is up to great debate, as endocrinologists and bioethicists are largely critical of the stance that male hormones, namely testosterone, in addition to other secondary sex characteristics, necessarily confer an inherent competitive advantage (Karkazis and Jordan-Young 2018).

34. Scholars delineate the specific harms endured by "trans* people in athletics (Buzuvis 2013; Davis 2017; Sinisi 2012; Skinner-Thompson and Turner 2014). The complex rules around physical transitions that define competitive eligibility for trans ${ }^{\star}$ athletes run parallel to issues for trans* inclusion in other policy arenas, including sex segregated restrooms, single-sex educational institutions, and state-issued identification documents (Davis 2014; Spade 2008). The definition of "sex" applied to athletics policy is less useful for genderbased forms of discrimination in education - particularly for trans ${ }^{\star}$ people whose identities frequently elide both a binary definition of gender, and/or a biological definition of sex. Rather than benefiting from inclusion through biologic definitions of "sex," trans ${ }^{\star}$ students are more often harmed by them.

35. This intractability of policy design echoes Katherine Franke's argument that this disaggregation of sex from gender in equality law is "the central mistake of equality jurisprudence" (Franke 1996, 2). Although discussions about transgender non-discrimination as protected under Title IX emerged decades after Franke's article regarding workplace discrimination, the point remains prescient:

Antidiscrimination law is founded upon the idea that sex, conceived as biological difference, is prior to, less normative than, and more real than gender. Yet in every way that matters, sex bears an epiphenomenal relationship to gender; that is, under close examination almost every claim with regard to sexual identity or sex discrimination can be shown to be grounded in normative gender rules and roles. Herein lies the mistake ... sexual equality jurisprudence has uncritically accepted the validity of biological sexual differences. By accepting these biological differences, equality jurisprudence reifies as foundational fact that which is really an effect of normative gender ideology. (Franke 1996, 2)

36. Women remain significantly under-represented in legislative bodies at all levels in the U.S. (CAWP 2017), and are therefore hamstrung in their efforts to achieve representation on in a profoundly partisan environment.

37. Title VII of the CRA prohibits employers from discriminating against employees on the basis of sex, race, color, national origin, and religion. It also applies to private and public colleges and universities, employment agencies, and labor organizations. The language in Title IX of the Education Amendments of 1972 is modeled on Title VII and Title VI (which prohibits discrimination by government agencies that receive federal funds) of the CRA (Pub. L. 88352).

38. Gendered inequalities are inflected through the intersecting dimensions of race, sexuality, class, and physical ability (Crenshaw 1991; Strolovitch 2007).

39. Ironically, youth sports, alongside recreational athletics, are some of the most fruitful locations for developing sex integrated praxis because they do not generally invoke the concerns about either embodied strength or physical intimacy between opposite-sex competitors.

40. Cisgender men athletes who comport with normative masculinity do not commonly confront this, although they receive similarly confusing signals from policy. Men and boys are taught, by the conditions of policy implementation thru sex segregated sports, that there are two types of athletic competitors: athletes and female athletes, and that "female athletes" require their protection instead of their unmitigated competitive respect. Gender policing also harms men whose gender challenges traditional masculinities (e.g., Messner 2011).

41. Pointedly, John McEnroe denigrated Serena Williams' prowess as a tennis player in the summer of 2017, suggesting that she would be low ranked "on the men's circuit" (ESPN 2017). 
42. McDonagh and Pappano (2007) explore many such examples, although the newly announced "hyperandrogenism" policy illustrates how such competitive achievements for women, under a segregated system, are subjected to scrutiny and retaliation (Karkazis and Jordan-Young 2018).

43. Nearly thirty-two percent of athletes surveyed in the study believed that "women and men should be permitted to participate on the same teams in non-contact sports."

44. Milner and Braddock (2016) argue for integration from the "bottom up," focusing on maintaining the more common practice of sex integrated youth sports into adolescence and relying on generational change.

\section{Acknowledgements}

For assistance in developing this manuscript, I would like to thank Patricia Strach, Julie Novkov, Mara Toone, Dara Strolovitch, Dara Cohen, Susan Moffitt, Barbara Cruikshank, Jesse Rhodes, Tatishe Nteta, Maxime Forest, Daniel Thompson, and the American Politics Workgroup at the University of Massachusetts Amherst. I am appreciative of comments from Nadia Brown, and those from anonymous reviewers, which helped me improve the manuscript. I also acknowledge research support from the American Academy of University Women, the Gerald R. Ford Presidential Foundation, the Social Science Research Council, the Myra Sadker Foundation, the New England Regional Fellowship Consortium, and the National Collegiate Athletic Association.

\section{Disclosure statement}

No potential conflict of interest was reported by the author.

\section{Funding}

This work was supported by the Gerald R. Ford Presidential Foundation; American Association of University Women; National Collegiate Athletic Association; New England Regional Fellowship Consortium; Myra Sadker Foundation; and the Social Science Research Council.

\section{ORCID}

Elizabeth A. Sharrow (D) http://orcid.org/0000-0001-5880-7905

\section{References}

Acklin, Kayla. 2017. "'Hurdling' Gender Identity Discrimination: The Implications of State Participation Policies on Transgender Youth Athletes' Ability to Thrive." Boston College Journal of Law \& Social Justice 37 (1): 107-145.

Anderson, Eric. 2008. “I Used to Think Women Were Weak': Orthodox Masculinity, Gender Segregation, and Sport.” Sociological Forum 23 (2): 257-280.

Balingit, Moriah. 2018. "Education Department No Longer Investigating Transgender Bathroom Complaints." Washington Post. Accessed 20 September 2018. https://www.washingtonpost. com/news/education/wp/2018/02/12/education-department-will-no-longer-investigatetransgender-bathroom-complaints/?utm_term=.15bb354da7c7.

Bell, Melina. 2016. "Gender Essentialism and American Law: Why and How to Sever the Connection." Duke Journal of Gender Law and Policy 23 (2): 189-221.

Bem, Sandra Lipsitz. 1993. The Lenses of Gender: Transforming the Debate on Sexual Inequality. New Haven, CT: Yale University Press.

Brake, Deborah. 2001. "The Struggle for Sex Equality in Sport and the Theory Behind Title IX." University of Michigan Journal of Law Reform 34 (1\&2): 13-149. 
Brake, Deborah. 2010. Getting in the Game: Title IX and the Women's Sports Revolution. New York: NYU Press.

Butler, Judith. 1990. Gender Trouble: Feminism and the Subversion of Identity. New York: Routledge.

Butler, Judith. 1993. Bodies That Matter: On the Discursive Limits of Sex. New York: Routledge.

Buzuvis, Erin. 2006. "Survey Says ... A Critical Analysis of the New Title IX Policy and a Proposal for Reform A Critical Analysis of the New Title IX.” Iowa Law Review 91: 821-883.

Buzuvis, Erin. 2011. "Transgender Student-Athletes and Sex-Segregated Sport: Developing Policies of Inclusion for Intercollegiate and Interscholastic Athletics.” Seton Hall Journal of Sports \& Entertainment Law 21 (11): 1-59.

Buzuvis, Erin. 2013. “'On the Basis of Sex': Using Title IX to Protect Transgender Students From Discrimination in Education.” Wisconsin Journal of Law, Gender \& Society 28 (3): 219-243.

Caggiano, Jessica Constance. 2010. “Girls Don’t Just Want to Have Fun: Moving Past Title IX’s Contact Sports Exception.” University of Pittsburgh Law Review 72 (1): 119-146.

Cahn, Susan. 1995. Coming on Strong: Gender and Sexuality in Twentieth-Century Women's Sport. Cambridge, MA: Harvard University Press.

CAWP (Center for American Women in Politics). 2017. "Women in Elected Office 2017." Accessed 13 July 2017. http://www.cawp.rutgers.edu/women-elective-office-2017.

Clarke, Phoebe, and Ian Ayres. 2014. "The Chastain Effect: Using Title IX to Measure the Causal Effect of Participating in High School Sports on Adult Women's Social Lives." The Journal of Socio-Economics 48: 62-71.

Cohen, David. 2011. "The Stubborn Persistence of Sex Segregation." Columbia Journal of Gender and Law 20 (1): 51-140.

Compton, Matt. 2012. "President Obama Talks Title IX.” WhiteHouse.gov. Accessed 2 October 2017. https://obamawhitehouse.archives.gov/blog/2012/03/26/president-obama-talks-title-ix.

Costain, Anne. 1981. "Representing Women: The Transition From Social Movement to Interest Group.” Western Political Quarterly 34 (1): 100-113.

Cott, Nancy. 1987. The Grounding of Modern Feminism. New Haven, CT: Yale University Press.

Crenshaw, Kimberle. 1991. "Mapping the Margins : Intersectionality, Identity Politics, and Violence Against Women of Color." Stanford Law Review 43 (6): 1241-1299.

Davis, Heath Fogg. 2014. "Sex-Classification Policies as Transgender Discrimination: An Intersectional Critique." Perspectives on Politics 12 (1): 45-60.

Davis, Heath Fogg. 2017. Beyond Trans: Does Gender Matter? New York: New York University Press.

Davis, Heath Fogg. 2018. "Why the 'Transgender' Bathroom Controversy Should Make Us Rethink Sex-Segregated Public Bathrooms." Politics, Groups, and Identities 6 (2): 199-216.

Dietz, Mary. 2003. "Current Controversies in Feminist Theory." Annual Review of Political Science 6 (1): 399-431.

Doyle, Jennifer. 2015. Campus Sex, Campus Security. Boston, MA: MIT Press.

Druckman, James, Jacob Rothschild, and Elizabeth Sharrow. 2018. "Gender Policy Feedback: Perceptions of Sex Equity, Title IX, and Political Mobilization Among College Athletes." Political Research Quarterly 71 (3): 642-653.

Edelman, Lauren. 2016. Working Law: Courts, Corporations, and Symbolic Civil Rights. Chicago, IL: University of Chicago Press.

Edwards, Amanda Ross. 2010. "Why Sport? The Development of Sport as a Policy Issue in Title IX of the Education Amendments of 1972." Journal of Policy History 22 (3): 300-336.

English, Ashley. 2016. "Rewriting Title IX: The Department of Education's Response to Feminists' Comments in the Rulemaking Process." Politics \& Gender 12 (3): 491-517.

ESPN. 2017. "John McEnroe: Serena Williams Would Be 'like No. 700 in World' on Men's Circuit." ESPN.com. Accessed 27 July 2017. http://www.espn.com/tennis/story/_/id/19734541/johnmcenroe-says-serena-williams-no-700-world-played-men-circuit.

Evans, Sara. 2010. Tidal Wave: How Women Changed America at Century's End. New York: Simon and Schuster. 
Fausto-Sterling, Anne. 2000. Sexing the Body: Gender Politics and the Construction of Sexuality. New York: Basic Books.

Fine, Cordelia. 2010. Delusions of Gender: How Our Minds, Society, and Neurosexism Create Difference. New York: W.W. Norton.

Fine, Cordelia. 2017. Testosterone Rex: Myths of Sex, Science, and Society. New York: W.W. Norton. Fishel, Andrew, and Janice Pottker. 1977. National Politics and Sex Discrimination in Education. Lexington, MA: Lexington Books.

Franke, Katherine. 1996. "The Central Mistake of Sex Discrimination Law: The Disaggregation of Sex From Gender." University of Pennsylvania Law Review 144: 1-100.

Fryer, Brit. 2018. "Global Sports Community Joins Athlete Ally and Women's Sports Foundation in Calling on IAAF to Rescind Discriminatory Policy." Athlete Ally. Accessed 5 October 2018. https://www.athleteally.org/iaafopenletter/.

George, B. Glenn. 2002. “Fifty / Fifty : Ending Sex Segregation in School Sports.” Ohio State Law Journal 63: 1107-1140.

Goss, Kristin. 2012. The Paradox of Gender Equality: How American Women's Groups Gained and Lost Their Public Voice. Ann Arbor, MI: University of Michigan Press.

Grossman, Joanna. 2016. Nine to Five: How Gender, Sex, and Sexuality Continue to Define the American Workplace. New York: Cambridge University Press.

Hochschild, Jennifer. 1984. The New American Dilemma: Liberal Democracy and School Desegregation. New Haven, CT: Yale University Press.

Hoye, Sarah. 2013. "Girl, 11, Scores in Fight against Philadelphia Archdiocese to Play Football." CNN.com. Accessed 20 March 2015. http://www.cnn.com/2013/03/14/us/philadelphiaarchdiocese-boys-only-football/index.html?hpt=us_c2.

Jordan-Young, Rebecca. 2010. Brain Storm: The Flaws in the Science of Sex Differences. Cambridge, MA: Harvard University Press.

Kaestner, Robert, and Xin Xu. 2010. “Title IX, Girls' Sports Participation, and Adult Female Physical Activity and Weight." Evaluation Review 34 (1): 52-78.

Karkazis, Katrina, and Rebecca Jordan-Young. 2018. “The Powers of Testosterone: Obscuring Race and Regional Bias in the Regulation of Women Athletes." Feminist Formations 30 (2): 1-39.

Karkazis, Katrina, Rebecca Jordan-Young, Georgiann Davis, and Silvia Camporesi. 2012. "Out of Bounds? A Critique of the New Policies on Hyperandrogenism in Elite Female Athletes." The American Journal of Bioethics 12 (7): 3-16.

Kessler, Suzanne, and Wendy McKenna. 1978. Gender: An Ethnomethodological Approach. Chicago, IL: University of Chicago Press.

Koss, Maddie. 2017. "No, They're Not Boys. But Madison Soccer Team Endures Criticism Because Players Have Short Hair." Milwaukee Journal Sentinel. Accessed 8 August 2017. http://www. jsonline.com/story/news/2017/08/05/madison-girls-soccer-team-bristles-critics-who-sayplayers-boys/459741001/.

Leong, Nancy. 2018. “Against Women's Sports.” Washington University Law Review 95 (1): 12491290.

Lorber, Judith. 1993. "Believing Is Seeing: Biology as Ideology.” Gender \& Society 7 (4): 568-581.

Love, Adam, and Kimberly Kelly. 2011. "Equity or Essentialism? U.S. Courts and the Legitimation of Girls' Teams in High School Sport.” Gender \& Society 25 (2): 227-249.

MacKenzie, Megan. 2015. Beyond the Band of Brothers: The US Military and the Myth That Women Can't Fight. New York: Cambridge University Press.

MacKinnon, Catharine. 1989. Toward a Feminist Theory of the State. Cambridge, MA: Harvard University Press.

Manne, Kate. 2017. Down Girl: The Logic of Misogyny. New York: Oxford University Press.

Mansbridge, Jane. 1986. Why We Lost the ERA. Chicago, IL: University of Chicago Press.

McDonagh, Eileen, and Laura Pappano. 2007. Playing With the Boys: Why Separate Is Not Equal in Sports. New York: Oxford University Press.

Meadow, Tey. 2010. “A Rose Is a Rose: On Producing Legal Gender Classifications.” Gender and Society 24 (6): 814-837. 
Meadow, Tey. 2018. Trans Kids: Being Gendered in the Twenty-First Century. Berkeley, CA: University of California Press.

Mele, Christopher. 2017. “They Thought I Was a Boy’: Short-Haired Girl Barred From Soccer Tournament.” New York Times. Accessed 7 August 2017. https://www.nytimes.com/2017/06/ 06/sports/girl-soccer-player.html?_r=0.

Menarndt, Will. 2018. "I Went To Kavanaugh's Alma Mater, Georgetown Prep, And It Was A Case Study In Misogyny.” The Establishment. Accessed 28 September 2018. https://theestablishment. co/i-went-to-kavanaughs-alma-mater-georgetown-prep-and-it-was-a-case-study-in-misogyny/.

Messner, Michael. 2011. "Gender Ideologies, Youth Sports, and the Production of Soft Essentialism.” Sociology of Sport Journal 28 (2): 151-170.

Meyerowitz, Joanne. 2004. How Sex Changed: A History of Transsexuality in the United States. Cambridge, MA: Harvard University Press.

Miller, Claire Cain. 2017. "When Job Puts Sexes Together, Workers Cringe.” New York Times: A1. Accessed 3 July 2017. https://www.nytimes.com/2017/07/01/upshot/members-of-the-oppositesex-at-work-gender-study.html?em_pos=small\&emc=edit_up_20170703\&nl=upshot\&nl_art= $0 \&$ nlid $=58140646 \&$ ref $=$ headline\&te $=1 \& \_r=1$.

Milner, Adrienne, and Jomills Henry Braddock. 2016. Sex Segregation in Sports: Why Separate Is Not Equal. New York: Praeger.

Nader, Ralph. 2003. "Join the Fight for Title IX.” Commondreams.org. Accessed 26 March 2013. http://www.commondreams.org/views03/0130-08.htm.

NCAA (National Collegiate Athletic Association). 2017a. NCAA Sports Sponsorship and Participation Rates Report, 1981-82-2016-17. Indianapolis, IN: National Collegiate Athletic Association.

NCAA (National Collegiate Athletic Association). 2017b. 45 Years of Title IX: The Status of Women in Intercollegiate Athletics. Indianapolis, IN: National Collegiate Athletic Association.

OCR (Office for Civil Rights in the U.S. Department of Education). 1996. "Clarification of Intercollegiate Athletics Policy Guidance: The Three-Part Test.” Accessed 8 March 2016. http://www2.ed.gov/about/offices/list/ocr/docs/clarific.html.

OCR (Office for Civil Rights in the U.S. Department of Health, Education and Welfare). 1979. "A Policy Interpretation: Title IX and Intercollegiate Athletics.” Federal Register, Vol. 44, No. 239. Accessed 8 March 2016. http://www2.ed.gov/about/offices/list/ocr/docs/t9interp.html.

Palin, Sarah. 2007. "Sarah Palin Interview." Alaska Business Monthly.

Pickett, Moneque Walker, Marvin Dawkins, and Jomills Henry Braddock. 2012. "Race and Gender Equity in Sports: Have White and African American Females Benefited Equally From Title IX?" American Behavioral Scientist 56 (11): 1581-1603.

Pieper, Lindsay Parks. 2016. Sex Testing: Gender Policing in Women's Sports. Urbana-Champagne: University of Illinois Press.

PSEW (Project on the Status and Education of Women). 1974. "What Constitutes Equality for Women in Sport? Federal Law Puts Women in the Running." Accessed 5 August 2017. http:// msa.maryland.gov/megafile/msa/speccol/sc3500/sc3520/015800/015858/pdf/sports_report.pdf.

Repo, Jemima. 2016. The Biopolitics of Gender. New York: Oxford University Press.

Reynolds, Celene. 2018. "The Mobilization of Title IX Across Colleges and Universities, 19942014.” Social Problems, doi:10.1093/socpro/spy005.

Ring, Jennifer. 2009. Stolen Bases: Why American Girls Don't Play Baseball. Champaign: University of Illinois Press.

Risman, Barbara. 2004. “Gender As a Social Structure: Theory Wrestling with Activism.” Gender \& Society 18 (4): 429-450.

Ritter, Gretchen. 2006. The Constitution as Social Design: Gender and Civic Membership in the American Constitutional Order. Palo Alto, CA: Stanford University Press.

Rose, Deondra. 2018. Citizens by Degree: Higher Education Policy and the Changing Gender Dynamics of American Citizenship. New York: Oxford University Press.

Sangree, Suzanne. 2000. "Title IX and the Contact Sports Exemption: Gender Stereotypes in a Civil Rights Statute." Connecticut Law Review 32 (2): 381-449. 
Sharrow, Elizabeth. 2017. “Female Athlete' Politic: Title IX and the Naturalization of Sex Difference in Public Policy.” Politics, Groups, and Identities 5 (1): 46-66.

Sinisi, Jennifer. 2012. "Gender Non-Conformity as a Foundation for Sex Discrimination: Why Title IX May Be an Appropriate Remedy for the NCAA’s Transgender Student-Athletes.” Villanova Law Review 19: 343-370.

Skinner-Thompson, Scott, and Ilona M Turner. 2014. “Title IX's Protections for Transgender Student Athletes." Wisconsin Journal of Law, Gender \& Society 28 (3): 271-300.

Smith, Thomas. 2017. "Not Throwing in the Towel: Challenging Exclusive Interscholastic Transgender Athletic Policies Under Title IX.” Jeffrey S. Moorad Sports Law Journal 24 (2): 309-349.

Spade, Dean. 2008. “Documenting Gender.” Hastings Law Journal 59: 731-842.

Staurowsky, Ellen, et al. 2015. Her Life Depends On It III: Sport, Physical Activity, and the Health and Well-Being of American Girls and Women. East Meadow, NY: Women's Sports Foundation.

Stevens, Matt. 2018. "California's Publicly Held Corporations Will Have to Include Women on Their Boards." New York Times. Accessed 30 September 2018. https://www.nytimes.com/ 2018/09/30/business/women-corporate-boards-california.html.

Stevenson, Betsey. 2010. "Beyond the Classroom: Using Title IX to Measure the Return to High School Sports." The Review of Economics and Statistics 92 (2): 284-301.

Strolovitch, Dara Z. 2007. Affirmative Advocacy: Race, Class, and Gender in Interest Group Politics. Chicago, IL: University of Chicago Press.

Strum, Philippa. 2004. Women in the Barracks: The VMI Case and Equal Rights. Lawrence, KS: University Press of Kansas.

Suggs, Welch. 2005. A Place on the Team: The Triumph and Tragedy of Title IX. Princeton, NJ: Princeton University Press.

Thomas, Gillian. 2016. Because of Sex: One Law, Ten Cases, and Fifty Years That Changed American Women's Lives at Work. New York: St. Martin's Press.

Tompkins, Avery. 2014. “Asterisk.” TSQ: Transgender Studies Quarterly 1 (1): 26-27.

Turk, Katherine. 2016. Equality on Trial: Gender and Rights in the Modern American Workplace. Philadelphia, PA: University of Pennsylvania Press.

Weil, Elizabeth. 2015. "Mary Cain Is Growing Up Fast.” New York Times Magazine: MM40. Accessed 4 March 2015. https://www.nytimes.com/2015/03/08/magazine/mary-cain-isgrowing-up-fast.html.

Whiteside, Erin, and Amber Roessner. 2018. "Forgotten and Left Behind: Political Apathy and Privilege at Title IXs 40th Anniversary." Communication \& Sport 6 (1): 3-24.

Yanus, Alixandra, and Karen O’Connor. 2016. "To Comply or Not to Comply: Evaluating Compliance with Title IX of the Educational Amendments of 1972." Journal of Women, Politics \& Policy 37 (3): 341-358.

YouGov. 2017. Title IX and Girls in Sport. East Meadow, NY: Women's Sports Foundation.

Young, Iris Marion. 1980. "Throwing Like a Girl: A Phenomenology of Feminine Body Comportment Motility and Spatiality." Human Studies 3 (1): 137-156. 